\title{
From growing convergence of spirituality and leadership towards a unified leadership theory
}

\author{
Puneet Bindlish \\ Management Development Institute, Gurgaon, India \\ Priyanka Dutt \\ IIS University, Jaipur, India \\ Rupali Pardasani \\ Management Development Institute, Gurgaon, India
}

\begin{abstract}
In recent times, researchers' interest in understanding the nature of leadership's relationship to spirituality has been fuelled by a striking commonality among successful leaders with regards to their spiritual propensities. More so, now that the issues such as business ethics, social responsibility and meaningfulness in work are taking prominence in organizations, the need for research is being felt to understand leadership from holistic dimensions. Traditionally, leadership and spirituality exist as two independent concepts, but leadership without spirituality is a state of "abridged development", a state that can be described as an atom without a nucleus. The relationship between spirituality and leadership is fundamental in nature and spans across various leadership styles/theories. The paper's intent is to share an indepth view on this imbricating relationship, thus providing impetus to the growing need for a holistic approach to leadership. The paper concludes with a discussion on the need for a unified model of leadership, with spirituality forming its bedrock. Such a bedrock lays the foundation for an individual to harness the potential that spirituality provides for unheralded growth in the area of management.
\end{abstract}

Keywords: Spirituality; Leadership; Spiritual leadership; Confluence; Convergence; Integral; Unified

Note: Terms marked with an asterisk are defined in the Glossary at the end of the paper.

\section{INTRODUCTION}

Bennis (2007) mentions nuclear or biological catastrophe, a worldwide pandemic, tribalism and "leadership of human institutions" as four challenges to world stability and asserts that without an exemplary leadership emanating from an integrated theory of leadership, the remaining three challenges cannot be solved. Our ways and thoughts on leadership have parallel changes in worldview and vice versa. Physics has always influenced the worldview of management, from its predictive deterministic scientific world view to the Darwinian world view. With the advent of new theories like theory of relativity, uncertainty, quantum entanglement, string theory and many more, modern physics is headed for a fresh start leading towards unified theories on matter, field, force and energy. At the subatomic level, physics is having its brush with spirituality. In management realms, a striking commonality among leaders in their spiritual propensities has been observed, leading to a growing interest by researchers in understanding the relationship between spirituality and leadership. Taking a clue from this observation and physicists' endeavour towards understanding the complexity of matter in a unified way, we can make a fresh start to understand complex observed phenomena in leadership like non-linear inculcation of traits, will power, leaders' connectedness with people and environment, the nature of higher purpose or pursuits, and their source of intrinsic motivation.

After reviewing academic literature on leadership and spirituality, the authors observed that these

Correspondence concerning this article should be addressed to Puneet Bindlish, Department of Organizational Behaviour, Management Development Institute, Gurgaon, Haryana, India. email: puneetbindlish@gmail.com 
terminologies exist as two independent concepts. But studying leadership without spirituality will be an incomplete study which can be termed as a state of "abridged development", a state that can be compared to an atom without a nucleus. This continuous relationship between spirituality and leadership spans across various leadership styles/theories and provides further impetus to the growing need for a holistic approach to spirituality, or a unifying theory of leadership based on spirituality. The paper concludes with a discussion on the need for a unified model of leadership. Certain indicative approaches that depict the imbricating relationship of the two concepts pave the way to harnessing the potential that spirituality provides for allround growth in the area of leadership.

The empirical research on leadership traditionally has a reasonably well-defined but narrow focus on various leadership aspects such as behaviours, power dimensions, traits and skills, and contexts. However, the qualitative research, including non-empirical, has led to other themes, such as leadership as a collective phenomenon (Drath \& Palus, 1994), the emergence of recognition of leadership as an outcome of an individual's spiritual core (Fairholm, 1998), and leadership as an outcome of an individual's thinking, inquiring, perceiving, valuing, and acting in a community rather than as an individual context (Eggert, 1998, p. 223). On the other hand, the concept of spirituality has attracted the academic community's attention, notably in the last two decades (Gibbons, 2011; Dent, Higgins \& Wharff, 2005). From best-selling books talking about spirituality, spirit and their causal connections with organization and individuals, to special mention in mainstream organization behaviour textbooks (Robbins, 2003), the concept is increasingly being talked about from various perspectives. However, most of the literature in this field has appeared in non-academic publications, ancient scriptures or as discourses by leaders. Academicians consider those as general writings that may lack research methodological rigor. And subsequently, it is not surprising that this field is marked by the typically evolutionary characteristics of paradigm development. This phase has been rightly known as the emerging stage of construct development introduction and elaboration (Reichers \& Schneider, 1990).

Studies in both the fields of spirituality and leadership are characterized by lack of consensus on definitions, assumptions, theories and methodologies, clarity about scope of the area with regards to contextual breadth and depth coverage. Therefore, spirituality and leadership studies are impacted time and again by the introduction of newer paradigms emerging in spirituality and leadership separately. We can observe similarities in the research in leadership and spirituality. These developments led to inclusion of the spiritual domain as an integral component of a leadership development model (Cook-Greuter, 2002; Sanders et al., 2003; Thompson, 2000; Wilber, 2000b).

Given the way research has progressed, leadership has been considered more of a science and spirituality more of a philosophy. This is because of the nature of the scientific approaches which were developed over a period of time that could more easily be applied to leadership. However, lack of scientific inquiry methodologies for spirituality led to its treatment more as philosophy than science. Therefore, as part of the methodology, the authors deliberated over various methodologies available for research in spirituality and leadership. More details are mentioned in the next section.

\section{METHODOLOGY}

Research in leadership has taken concrete shape and is influencing practice. Research in spirituality is nascent, with unsettled debates, especially with regard to the epistemological and ontological assumptions as challenges within this field. Consequently, the research approaches to the study of spirituality have been evolving. Some transpersonal approaches have been acknowledged as valid methods for research in spirituality, including integral Inquiry, intuitive Inquiry, organic research, phenomenological inquiry, informed exceptional human experience inquiry etc. (Braud \& Anderson, 1998). Even after these developments, the methods still emanate from anthropocentric and scientific worldviews and are yet to incorporate ancient ways emanating from biocentric worldviews to full strength. For instance, here are two shlokas* from Indian scriptures on how true knowledge is established about any subject, especially spirituality:

$$
\text { प्रत्टक्षानुमनागामः प्रमाणानि। }
$$

\section{Pratyaksha Anumana Agamah Pramanani (Maharishi Patanjali's Yog Sutra 1.7)}

Correct perception may be acquired directly, by correct analysis or by correct reference. The reference here implies scriptures or verbal testimony received from the Guru, on which there is absolute faith and no doubt. 


\section{तानी प्रमानानी सत प्रत्यक्षानुमनओपमानासब्दार्थापत्त्ययानुपलाब्धिभेदत।}

Tani pramanani sat pratyaksanumanopamanasabdarthapattyyanupalabdhibhedat

Mimansa Sastra describes the means of true and valid knowledge to have six parts - Pratyaksha* , Anumana*, Upamana*, Agama*, Arthapatti *and Anupalapdhi* (Bhatt, 1989). The theory development in the field of this concept too has to develop these six parts to be able to reach a stage of true and valid knowledge.

The research methodologies mentioned above incorporate all the above means except Agama. Maharishi Vyasa in his commentary on Patanjali Yog Sutra, mentions that, to understand the issues which go beyond the reach of human intellect, Agama or shruti is the only means to acquire the knowledge of that issue or object. Shruti has been accepted as the final source, since it is apourusheya*. Apourusheya of Agama: no authorship and devoid of human ego, degree of comprehensiveness, no contradictions in the shrutis, its spelling, punctuations and intonations retained over time. How did the shrutis come about? Sri Krishna in Bhagwad Gita Chapter 10, Verse 6:

\section{महर्षयः सप्त पूर्वे चत्वारो मनवस्तथा ।}

\section{मदभावा मानसा जाता येषां लोक इमाः प्रजाः ।}

maharshyah sapt poorve chatvaro manvasttha |

madbhaava mansa jaata yesham lok imah prajah ||

Seven great sages (also referred to as mantradrishta): Marici, Atri, Angiras, Pulastya, Pulaha, Kratu and Vasistha in earlier ages, also the four Manus: Svayambhuva, Svarochita, Raivata and Uttama all manifested from mental impulses originating from Me (Lord Krishna, Almighty), populating all existing progeny in the material universes.

These were the sages, to whom the Vedas were revealed in their meditation (they were not the creators). Therefore issues related to spirituality which include dharma*, nature of Brahman* and nature of jiva* have to be understood from the Agama.

On our literature research and review, it was found that there is a substantial body of literature which exists in the field of leadership, but the field of spirituality research is relatively new and therefore not many specific journals exist on this subject. Some of the prominent broad-based publications have been included, where most of the publications around these concepts were reported, viz. Academy of Management Executive, Human Relations, International Journal of Career Management, International Journal of Social Economics, Journal of Business Ethics, Journal of Management Inquiry, Journal of Management, Spirituality and Religion, Journal of Managerial Psychology, Journal of Organizational Change Management, Journal of Transpersonal Psychology, Journal of Workplace Learning, Leadership and Organization Development Journal , Proceedings of the Academy of Management, The Leadership Quarterly (partial list). Papers were reviewed for features such as relevance, country, timeline, level of research, research paradigm, research methodologies etc. Incidentally, a majority of literature was from a particular worldview that involved scientific methodologies as the dominant research paradigm developed over a period of time sharing a common worldview.

For this study, we have maintained an open approach by reviewing work from both dominant and other paradigms on leadership, spirituality and spirituality in leadership. The authors spent time with people with spiritual propensities together with their own experience, leading to emergence of certain themes when they were seen alongside various philosophies of spirituality and leadership. When it came to reading ancient scriptures or understanding the spiritual traits from spiritual leaders, the spiritual etiquette (spiritual prerequisites or shishya lakshan*) had to be observed. In the latter part of the paper, especially that which deals with the need for a unified theory of leadership with spirituality as its basis, the authors also included some of the eastern scriptures observing the protocol (spiritual prerequisites or shishya lakshan) for receiving the knowledge from those scriptures.

\section{SPIRITUALITY}

As mentioned in the introduction, it is significant that the theory development of spirituality and its relationship to leadership is in construct development phase (Reichers \& Schneider, 1990). It is therefore 
characterized by endeavours for greater acceptance of the new construct. Further commentaries on these endeavours lending agreement, evaluation, argument, consolidation through debates and critiques that finally settle controversies will eventually lead to the standardization of constructs. This cycle is repeated to generate and standardize the common definitions in the area, paving the way for further rigorous empirical research. A similar process happened to arrive at the definitions and relationships with other factors and outcomes. For instance, scholars link spirituality to organizational leadership (Fairholm, 1998; Fry, 2003; Strack et al., 2002) as well as other organizational factors such as absenteeism, productivity, turnover, ethicality, stress, and health (Giacalone \& Jurkiewicz, 2003). Some writers believe in enhancing organizational learning (Bierly, Kessler \& Christensen, 2000), unifying and building communities (Cavanaugh et al., 2001), serving the need for connecting to others at work, and to work itself (Khanna \& Srinivas, 2000), and as the source of a healing and harmonizing expression of compassion, wisdom, and connectedness instilling a sense of the spiritual realm at the individual, team, and organizational level.

\section{Aspects of Spirituality}

The following summary is presented in the form of a table (Table 1) and clearly delineates the various aspects of spirituality being researched in terms of categories of difference and distinction. The table is adapted from Dent, Higgins \& Wharff (2005).

Table 1: Aspects of Spirituality

\begin{tabular}{|c|c|c|}
\hline Aspect & Description & $\begin{array}{l}\text { Key words, salient } \\
\text { characteristics }\end{array}$ \\
\hline $\begin{array}{l}\text { Definitions } \\
\text { (Mohamed, Hassan, \& } \\
\text { Wisnieski, 2001; } \\
\text { Howard, 2002; Sharma, } \\
\text { 2010; Fry, 2003; Mason } \\
\text { \& Welsh, 1994) }\end{array}$ & $\begin{array}{l}\text { It's an individual, personal as well as inclusive and } \\
\text { universal phenomenon at the same time: } \\
\text { "The values, attitudes, and behaviours necessary to } \\
\text { intrinsically motivate oneself and others so that they } \\
\text { have a sense of spiritual survival through calling and } \\
\text { membership". "The desire to find ultimate purpose in } \\
\text { life and to live accordingly". }\end{array}$ & $\begin{array}{l}\text { Wonder, play, ignorance, } \\
\text { spontaneity, joy, } \\
\text { imagination, celebration, } \\
\text { discernment, insight, } \\
\text { creativity, calling, purpose, } \\
\text { membership }\end{array}$ \\
\hline $\begin{array}{l}\text { Manifestation of } \\
\text { spiritual development } \\
\text { (Delbecq, 1999) }\end{array}$ & $\begin{array}{l}\text { Series of discontinuous transforming, awakening, } \\
\text { suffering experiences. Continuous development of } \\
\text { spirituality through reflective thinking characterized } \\
\text { by discontinuous awakening events. }\end{array}$ & $\begin{array}{l}\text { Subconscious, } \\
\text { manifestation, grounding, } \\
\text { making the spiritual } \\
\text { physical element }\end{array}$ \\
\hline $\begin{array}{l}\text { Derived definition } \\
\text { (Avolio et al., 2004) }\end{array}$ & $\begin{array}{l}\text { Person possessing a sense of higher purpose and } \\
\text { faith, ability to real-time witness one's thoughts and } \\
\text { action based on that, sense of connectedness, drive } \\
\text { to serve. }\end{array}$ & $\begin{array}{l}\text { Higher purpose, faith, } \\
\text { connectedness, serving }\end{array}$ \\
\hline $\begin{array}{l}\text { Individual development } \\
\text { and spiritual } \\
\text { transformation } \\
\text { (Benefiel, 2005; Wilber, } \\
\text { 2000a) }\end{array}$ & $\begin{array}{l}\text { A journey, a non-linear phenomenon, in a linear } \\
\text { representation. }\end{array}$ & $\begin{array}{l}\text { Spirituality; spiritual } \\
\text { transformation }\end{array}$ \\
\hline $\begin{array}{l}\text { Measurable aspect } \\
\text { (Ashmos \& Duchon, }^{1} \\
\text { 2000; Bell \& Taylor, } \\
\text { 2001; MacDonald et } \\
\text { al., 1999; Cacioppe, } \\
\text { 2000; Wilber, 2000b) }\end{array}$ & $\begin{array}{l}\text { Researchers believe it's measurable but yet to } \\
\text { establish operationalized measurable constructs. } \\
\text { Significant group of researchers who believe that } \\
\text { spirituality cannot be measured. Wharff et al. (2005) } \\
\text { argue that even if we can't measure spirituality, we } \\
\text { can measure closely correlated manifestations of } \\
\text { spirituality. However, ensuring that proxies are close } \\
\text { enough to revealing the phenomenon is challenging. } \\
\text { Most instruments may be subject to a self-fulfilling } \\
\text { prophecy flaw. }\end{array}$ & $\begin{array}{l}\text { Measurable, ineffable or } \\
\text { ephemeral }\end{array}$ \\
\hline
\end{tabular}




\begin{tabular}{|l|l|l}
\hline $\begin{array}{l}\text { Organizational } \\
\text { performance indicators } \\
\text { (Reave, 2005) }\end{array}$ & $\begin{array}{l}\text { Spiritually empowered people show high ratings on } \\
\text { traits like creativity, honesty, strength, ethics, trust, } \\
\text { resilience etc. Increased productivity, lower attrition, } \\
\text { sustainability thus leading to productivity. }\end{array}$ & $\begin{array}{l}\text { Impacts organizational } \\
\text { performance }\end{array}$ \\
\hline
\end{tabular}

1 Additional note on some of the attempts on operationalizing constructs:

- Conceptualized as contribution to inner life, meaningful work, and community. Measured with 34item inventory using a 7-point Likert scale. (Ashmos \& Duchon, 2000)

- Measurement of dimensions of language and spirituality values (belief, journey, unity, higher power, and personal fulfillment). (Bell \& Taylor, 2001)

- From Expressions of Spirituality Inventory (cognitive orientation toward spirituality, experiential/phenomenological dimension, existential well-being, paranormal beliefs, and religiousness). (MacDonald, Kuentzel \& Friedman, 1999)

- $\quad$ Psychomatrix Spirituality Inventory (awareness of higher power, spiritual activities or practices, use of healing practices, experience of physical and emotional trauma, body awareness, religious history, and current religious practices). (Wolman, 2001)

Through using different terms and approaches, researchers on individual development have all put transcendence as the ultimate destination of the path. For instance, in Kabir-Gorakh Samvaad (an old Indian spiritual scripture), Sant Kabir mentions the sequence of spiritual development of an individual: Karma* $\rightarrow$ Chitta Shuddhi* $\rightarrow$ Bhakti/Upasana* $\rightarrow$ Samadhi*/ ekagra chitta* $\rightarrow$ gyan* $\rightarrow$ moksha*.

Similar references come from ancient and contemporary literature all across the world. As evident from the table also, despite some opposing arguments, there are common threads which are worth pursuing from a practitioner's perspective. Apart from transcendence, prominent among them are spirituality's impact on individual leadership development, its sustenance and by consequence, sustained organizational performance.

\title{
LEADERSHIP
}

Earlier research on leadership from the social science aspect used reductionism in the understanding of this social phenomenon. A review by Rost (1993) and Barker (2002) of leadership definitions concluded with a fivepoint definition of leadership and asserted that leadership is about two things - process and behaviours which in fact had the same reductionist flaw. An integrative definition was given by Patterson (2003):

\begin{abstract}
A leader is one or more people who selects, equips, trains, and influences one or more follower(s) who have diverse gifts, abilities, and skills and focuses the follower(s) to the organization's mission and objectives causing the follower(s) to willingly and enthusiastically expend spiritual, emotional, and physical energy in a concerted coordinated effort to achieve the organizational mission and objectives. The Leader achieves personal growth, renewal, regeneration and increased stamina not only for his/her own self but also through leader/follower interactions. The leader recognizes the diversity of the followers and ensures that the desired objectives are achieved by the followers' own learning. This can be a result of their own or others' successes, mistakes and failures along the path of completion of objectives.
\end{abstract}

Let's now look at various leadership theories and models from the literature. This is being done to bring out common characteristics among them in order to establish relationship with spirituality and further examine the possibility of a unified model or a paradigm for leadership.

\section{Leadership Theories/Models}

Leadership has been looked upon from various aspects and world views. Here is a review of prominent research that delineates the common characteristics. These theories have been divided into two sections: Western (Table 2) and Eastern/Oriental (Table 3), in order to highlight that the dominant paradigm has a bearing on deriving commonalities. 
Table 2: Leadership Theories/Models

\begin{tabular}{|c|c|c|}
\hline Theory & Description & Common Characteristics \\
\hline $\begin{array}{l}\text { Behavioural Theory (Skinner, 1967; } \\
\text { Bandura, 1982) }\end{array}$ & $\begin{array}{l}\text { Leadership traits or behaviours can } \\
\text { be taught, thus anyone can be } \\
\text { made a leader }\end{array}$ & $\begin{array}{l}\text { Interpersonal conflict, } \\
\text { psychological contract }\end{array}$ \\
\hline Contingency Model (Fiedler, 1960s) & $\begin{array}{l}\text { Effectiveness is based on the } \\
\text { situation, which is the result of two } \\
\text { factors: "leadership style" and } \\
\text { "situational favourableness" }\end{array}$ & $\begin{array}{l}\text { Contingency model of leadership } \\
\text { effectiveness, index terms, } \\
\text { endurance, leadership skills } \\
\text { approach, style approach; } \\
\text { contingency theory }\end{array}$ \\
\hline Path Goal Theory (House, 1971) & $\begin{array}{l}\text { Leader's behaviour affects } \\
\text { subordinate satisfaction, } \\
\text { motivation and performance, by } \\
\text { removing obstacles or creating } \\
\text { bigger roadblocks in his followers' } \\
\text { path }\end{array}$ & $\begin{array}{l}\text { Lessons, legacy, performance, } \\
\text { satisfaction, motivation, leadership }\end{array}$ \\
\hline Process Theory (J. Krantz, 1990) & $\begin{array}{l}\text { Leadership and followership as } \\
\text { interdependent; extends the role of } \\
\text { the follower to a position of high } \\
\text { trust. }\end{array}$ & $\begin{array}{l}\text { Trust, intimacy, subtlety, reduced } \\
\text { control, humility, leader as } \\
\text { facilitator }\end{array}$ \\
\hline $\begin{array}{l}\text { Shared, Collective or Distributed } \\
\text { Leadership (Pearce \& Conger, 2003) }\end{array}$ & $\begin{array}{l}\text { Interactive influence process that } \\
\text { involves peer, lateral, upward and } \\
\text { downward influence amongst the } \\
\text { group members for achieving } \\
\text { group/organizational goals. }\end{array}$ & $\begin{array}{l}\text { Authentic leadership, cognitive } \\
\text { leadership, complexity leadership, } \\
\text { cross, shared, collective, or } \\
\text { distributed leadership }\end{array}$ \\
\hline $\begin{array}{l}\text { The Great Man Theory (Plato, } \\
\text { Aristotle, Lao Tzu, Machiavelli, } \\
\text { Carlyle) }\end{array}$ & $\begin{array}{l}\text { Leader is born and not made. } \\
\text { Leader places the well-being of all } \\
\text { above self and takes righteous } \\
\text { actions }\end{array}$ & Employee centred, socio-emotional \\
\hline $\begin{array}{l}\text { The Trait Theory (Cheryl Mabey; } \\
\text { Bass and Stogdill, 1990) }\end{array}$ & $\begin{array}{l}\text { Acquisition of certain personality } \\
\text { attributes associated with leaders }\end{array}$ & $\begin{array}{l}\text { Implicit theories, traits, cultural } \\
\text { psychology }\end{array}$ \\
\hline
\end{tabular}


Table 3: Some of the Eastern and Oriental Models of Leadership

\begin{tabular}{|c|c|c|}
\hline Theory & Description & Common Characteristics \\
\hline $\begin{array}{l}\text { Vijigshu* Model } \\
\text { (Kautilaya) (Sharma, 2002) }\end{array}$ & $\begin{array}{l}\text { Requires the king or the leader to be self- } \\
\text { motivated and driven by victory orientation. }\end{array}$ & $\begin{array}{l}\text { Uses Sam*, Dam*, Dand* and } \\
\text { Bhed* for loksangraha* }\end{array}$ \\
\hline $\begin{array}{l}\text { Nurturant-Task } \\
\text { Leadership (Sinha, 1980) }\end{array}$ & $\begin{array}{l}\text { Taking care of subordinates, being } \\
\text { considerate and affectionate, consequently } \\
\text { contingent on task performance. }\end{array}$ & $\begin{array}{l}\text { Sneh* (to those who perform well } \\
\text { and are dedicated), shradha* } \\
\text { (shown by subordinates in } \\
\text { reciprocation) }\end{array}$ \\
\hline $\begin{array}{l}\text { Karta Model (Singh \& } \\
\text { Bhandarkar, 1990) }\end{array}$ & $\begin{array}{l}\text { Leader as karta*. Like a father figure in order } \\
\text { to be effective. Empowers, protects, grooms } \\
\text { and develops. }\end{array}$ & Protector and guardian \\
\hline $\begin{array}{l}\text { Four Steps Enlightened } \\
\text { Leadership (Sharma, } \\
\text { 1995) }\end{array}$ & $\begin{array}{l}\text { Harmonizes vision, mission and action } \\
\text { through higher order purpose for existence, } \\
\text { values, both yang and yin qualities. }\end{array}$ & $\begin{array}{l}\text { Vision, enlightenment, devotion } \\
\text { and action, higher purpose }\end{array}$ \\
\hline $\begin{array}{l}\text { Yin-Trinity Model } \\
\text { (Sharma, 1996) }\end{array}$ & $\begin{array}{l}\text { Originated from yin-trinity/female trinity of } \\
\text { Laxmi, Saraswati and Durga symbolizing } \\
\text { wealth, knowledge and power respectively. }\end{array}$ & $\begin{array}{l}\text { Righteous use of wealth, } \\
\text { knowledge and power }\end{array}$ \\
\hline $\begin{array}{l}\text { Theory K Model of } \\
\text { Enlightened Leadership } \\
\text { (Sharma, 1998) }\end{array}$ & $\begin{array}{l}\text { Classifies humans into three types: tamsik, } \\
\text { rajasik and sattavik, depending upon their } \\
\text { dominant guna. Practical ideal is to move } \\
\text { away from the tamsik qualities to rajasik and } \\
\text { sattavik qualities. }\end{array}$ & $\begin{array}{l}\text { Equanimity beyond three gunas: } \\
\text { Tamas*, rajas* and sattva* ('K' has } \\
\text { multiple associations: karta, karma, } \\
\text { kutumbh, karuna, kesri) }\end{array}$ \\
\hline $\begin{array}{l}\text { Workship Model } \\
\text { (Chatterjee, 1998) }\end{array}$ & $\begin{array}{l}\text { Four paths towards workship ("When work is } \\
\text { done in the spirit of worship, the quality of } \\
\text { work undergoes a metamorphosis. As a } \\
\text { result, even ordinary work is transformed } \\
\text { from a mere chore to an extraordinary } \\
\text { reality...") } \\
\text { Among them, transcendence is defined as a } \\
\text { state of realization in action. }\end{array}$ & $\begin{array}{l}\text { Discipline, righteousness, sacrifice, } \\
\text { and transcendence }\end{array}$ \\
\hline $\begin{array}{l}\text { Wisdom Leadership } \\
\text { (Chakraborty, 1999) }\end{array}$ & $\begin{array}{l}\text { Rooted in the ancient Rajrishi* model } \\
\text { wherein a leader has a touch of Rishi* or the } \\
\text { touch of sacredness in all his actions. }\end{array}$ & \\
\hline $\begin{array}{l}\text { The 24-Hour Leader } \\
\text { (Bhatta, 2000) }\end{array}$ & $\begin{array}{l}\text { Based on the ancient concept of the leader's } \\
\text { responsibilities towards his people/followers. }\end{array}$ & $\begin{array}{l}\text { Leaders owe to people. Pays entire } \\
\text { attention to lead people }\end{array}$ \\
\hline $\begin{array}{l}\text { Rishi as Re-see Model } \\
\text { (Sharma, 2001) }\end{array}$ & $\begin{array}{l}\text { Rishi is one who can re-see the things, events } \\
\text { and actions in a new perspective in addition } \\
\text { to providing a touch of humanness. }\end{array}$ & $\begin{array}{l}\text { Self-responsible individual and } \\
\text { matured, self-responsible } \\
\text { individual }\end{array}$ \\
\hline $\begin{array}{l}\text { Kautilya model (Jain \& } \\
\text { Mukherjee, 2009) }\end{array}$ & $\begin{array}{l}\text { Leader must have inherent potential to } \\
\text { absorb teachings given by experts. }\end{array}$ & $\begin{array}{l}\text { Sharp mind, physical } \\
\text { energy, resoluteness of purpose } \\
\text { and capacity for learning and } \\
\text { retention, skill in statecraft, } \\
\text { corporate warfare, economics and } \\
\text { diplomacy }\end{array}$ \\
\hline $\begin{array}{l}\text { Panchsheela Model (Jain, } \\
\text { 2011) }\end{array}$ & $\begin{array}{l}\text { Panchsheela* means five principles or vows } \\
\text { which form a practical code of conduct for a } \\
\text { leader. }\end{array}$ & $\begin{array}{l}\text { Panchmah* avrata (five principles) } \\
\text { are: Satya*, Ahimsa*, Asteya*, } \\
\text { Aparigraha* and Brahmacharaya* }\end{array}$ \\
\hline
\end{tabular}




\section{Leadership Styles}

Leadership can no longer be simply described as an individual characteristic or difference, but rather is depicted in various models as dyadic, shared, relational, strategic, global, and a complex social dynamic (Avolio, 2007; Yukl, 2006). Avolio and Luthans (2006) define authentic leadership as "a process that draws from both positive psychological capacities and a highly developed organizational context, which results in both greater self-awareness and self-regulated positive behaviours on the part of leaders and associates, fostering positive self-development." Future research would need to offer additional evidence for the constructs such as moral perspective, self-concept clarity, well-being, spirituality, and judgment. (Kindly refer to Table 4 for details.)

Table 4: Leadership Styles

\begin{tabular}{|c|c|c|}
\hline Leadership Style & Description & Common Characteristics \\
\hline $\begin{array}{l}\text { Charismatic Leadership } \\
\text { (Bass, 1997; Burns, } \\
\text { 1978; Rosner, 1990) }\end{array}$ & $\begin{array}{l}\text { Gathers followers through dint of personality and } \\
\text { charm. People follow others that they personally } \\
\text { admire. }\end{array}$ & $\begin{array}{l}\text { Self-confidence, strong } \\
\text { vision, ability to articulate } \\
\text { the vision, and willingness } \\
\text { to make radical changes }\end{array}$ \\
\hline $\begin{array}{l}\text { Complexity Leadership } \\
\text { (Hazy et al., 2007, p. 2) }\end{array}$ & $\begin{array}{l}\text { An interactive system of dynamic, unpredictable } \\
\text { agents that interact with each other in complex } \\
\text { feedback networks, which can then produce adaptive } \\
\text { outcomes such as knowledge dissemination, learning, } \\
\text { innovation, and further adaptation to change. }\end{array}$ & $\begin{array}{l}\text { Leadership, complexity } \\
\text { theory, complex adaptive } \\
\text { system }\end{array}$ \\
\hline $\begin{array}{l}\text { Emotional Leadership } \\
\text { (Lord, De Vader \& } \\
\text { Alliger, 1986) }\end{array}$ & $\begin{array}{l}\text { Empathy, ability to comprehend one's own and others' } \\
\text { feelings, facial expression influence environment, } \\
\text { create shared emotional experiences. }\end{array}$ & $\begin{array}{l}\text { Empathy, shared emotional } \\
\text { experiences, }\end{array}$ \\
\hline $\begin{array}{l}\text { Global Leadership } \\
\text { (Mobley, 1999; } \\
\text { Goldsmith, 2003; Lane } \\
\text { et al., 2004) }\end{array}$ & $\begin{array}{l}\text { Focuses on developing competencies in a leader } \\
\text { needed to effectively and successfully lead across } \\
\text { cultures learnt through global exposure }\end{array}$ & $\begin{array}{l}\text { Global leadership, } \\
\text { leadership characteristic, } \\
\text { strategic focus }\end{array}$ \\
\hline $\begin{array}{l}\text { New Genre Leadership } \\
\text { (Burns, 1978; Bass, } \\
\text { 1985) }\end{array}$ & $\begin{array}{l}\text { Emphasis on symbolic leader behaviour, visionary, } \\
\text { inspirational messages, emotional feelings and } \\
\text { intellectual stimulation. }\end{array}$ & $\begin{array}{l}\text { Leadership interventions, } \\
\text { meta-analysis, new genre }\end{array}$ \\
\hline $\begin{array}{l}\text { Self-Leadership (Manz } \\
\& \text { Sims, 1980) }\end{array}$ & $\begin{array}{l}\text { It equates to the leadership competencies of Self- } \\
\text { Observation and Self-Management. }\end{array}$ & $\begin{array}{l}\text { Self-observation, self- } \\
\text { management }\end{array}$ \\
\hline $\begin{array}{l}\text { Servant Leadership } \\
\text { (Russell \& Stone, 2002) }\end{array}$ & $\begin{array}{l}\text { Categorized as: functional and accompanying } \\
\text { attributes. Former includes vision, honesty, trust, } \\
\text { service orientation, a role model, appreciation of } \\
\text { others' service, and empowerment. Latter are } \\
\text { described as good communicators and listeners, } \\
\text { credible, competent, encouraging of others, teachers, } \\
\text { and delegators. }\end{array}$ & $\begin{array}{l}\text { Listening, empathy, healing, } \\
\text { awareness, persuasion, } \\
\text { conceptualization, foresight, } \\
\text { stewardship, commitment } \\
\text { and building community }\end{array}$ \\
\hline $\begin{array}{l}\text { Servant Leadership } \\
\text { (Robert K. Greenleaf, } \\
\text { 1970) }\end{array}$ & $\begin{array}{l}\text { Humble stewards of their organization's resources: } \\
\text { human, financial and physical. Natural feeling that one } \\
\text { wants to serve, to serve first. }\end{array}$ & Leadership, stewardship \\
\hline $\begin{array}{l}\text { Situational Leadership } \\
\text { (Vroom \& Yetton, } \\
\text { 1973) }\end{array}$ & $\begin{array}{l}\text { Emphasis on task and relationship behaviours to best } \\
\text { deal with different levels of follower maturity which } \\
\text { includes various styles of managing situations. }\end{array}$ & $\begin{array}{l}\text { Supportive, persuasive, } \\
\text { control-driven, participative } \\
\text { decision-making }\end{array}$ \\
\hline
\end{tabular}




\begin{tabular}{|l|l|l|}
\hline $\begin{array}{l}\text { Transactional } \\
\text { Leadership (Bass, 1997; } \\
\text { Burns, 1978; Rosner, } \\
\text { 1990) }\end{array}$ & $\begin{array}{l}\text { State clear instructions to the followers for the } \\
\text { expectation of work and consider rewards and } \\
\text { punishments as motivators for getting the work done. }\end{array}$ & $\begin{array}{l}\text { Transactional leadership, } \\
\text { job success and } \\
\text { transformational leadership }\end{array}$ \\
\hline $\begin{array}{l}\text { Transformational } \\
\text { Leadership (Bass, 2000; } \\
\begin{array}{l}\text { MacGregor Burns, } \\
\text { 1960) }\end{array}\end{array}$ & $\begin{array}{l}\text { "Move followers to go beyond their own self-interests } \\
\text { for the good of their group, organization or } \\
\text { community, country or society as a whole". }\end{array}$ & $\begin{array}{l}\text { Transformational } \\
\text { leadership, styles, change } \\
\text { leadership }\end{array}$ \\
\hline
\end{tabular}

Other leadership theories and types reviewed included: dyad linkage theory (Dansereau, 1996; Dansereau, Graen \& Haga, 1975; Dansereau \& Yammarino, 1998); leader-member exchange theory (Seibert, Sparrowe \& Liden, 2003 ); narcissistic leadership (Glad, 2002; Miliora, 1995; Zee, 1980; Chernow, 2004; Robins \& Paulhus, 2001; Kramer, 2003; Kimhi, 2001; Renshon, 2001; Krugman, 2005; Suskind, 2004; Stogdill, 1948); e-leadership (Avolio et al., 2001; Zigurs, 2003).

\section{INTEGRATION OF SPIRITUALITY AND LEADERSHIP}

After recognising the need for integrating spirituality and leadership, several researchers have attempted to marry the two concepts. Some of the closest attempts are:

1. Sharma (2010) put forth the following model:-

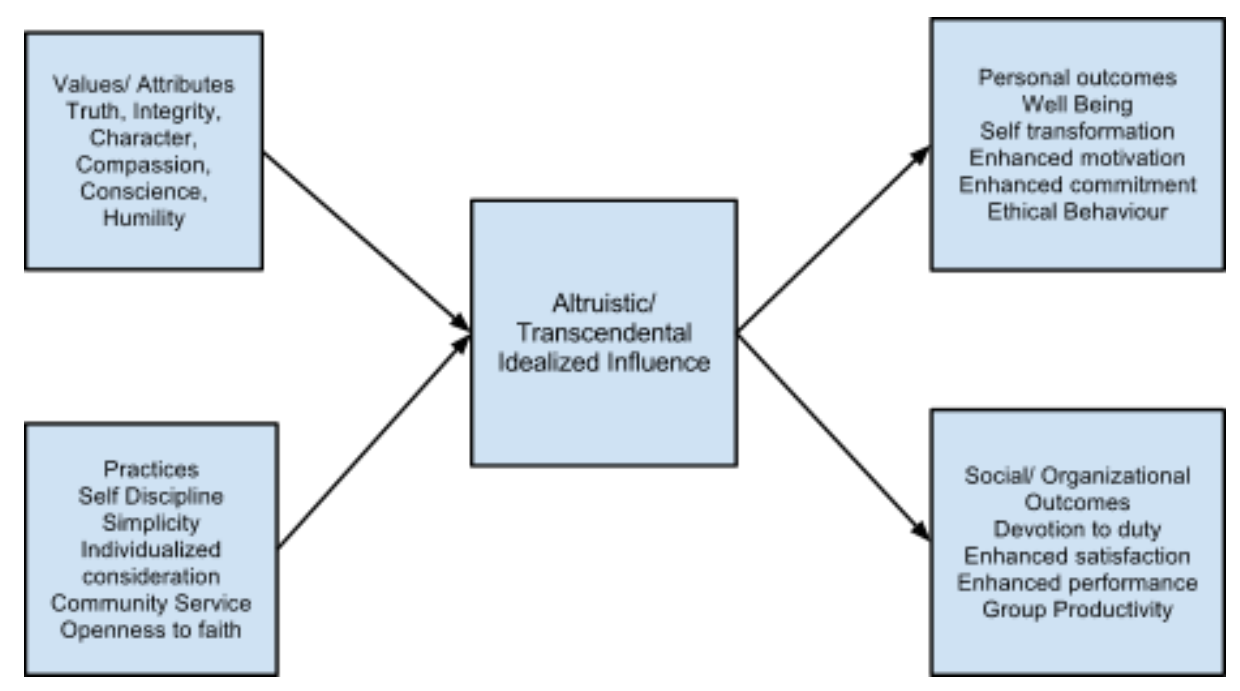

Figure 1: Model of Spiritual Leadership (Sharma,2010)

2. Spiritual Leadership: Fry (2003) describes this as "the effect of spiritual leadership brings together or creates a sense of fusion among the four fundamentals of human existence (body, mind, heart and spirit) so that people are motivated for high performance, have increased organizational commitment and personally experience joy, peace and serenity". Some of the key characteristics mentioned in the literature are: Vision ${ }^{1}$ (Griffin, 2004), Altruistic Love, Trust/Loyalty, Forgiveness/Acceptance/Gratitude, Character, Integrity, Honesty, Courage, Humility, Kindness/Compassion, Concern for others, Patience/Meekness/Endurance, Altruistic Goal or work as calling (Pfeffer \& Salancik, 2003), Intrinsic Motivation (Giacalone, 2003), Character and Integrity (Fry, 2003), Honest Communication (Elm, 2003), Conscience and values (Bass, 1998), Hope/Faith, Endurance, Perseverance, Do What it Takes, Stretch Goals, Expectation of reward/victory, Excellence, Concern for others

1 Vision: Broad appeal to key stakeholders, defines the destination and journey, reflects high ideals, encourages hope/faith, establishes standard of excellence. 
(Bass, 1998). According to Fry's (2003) model, spiritual leadership is depicted thus:

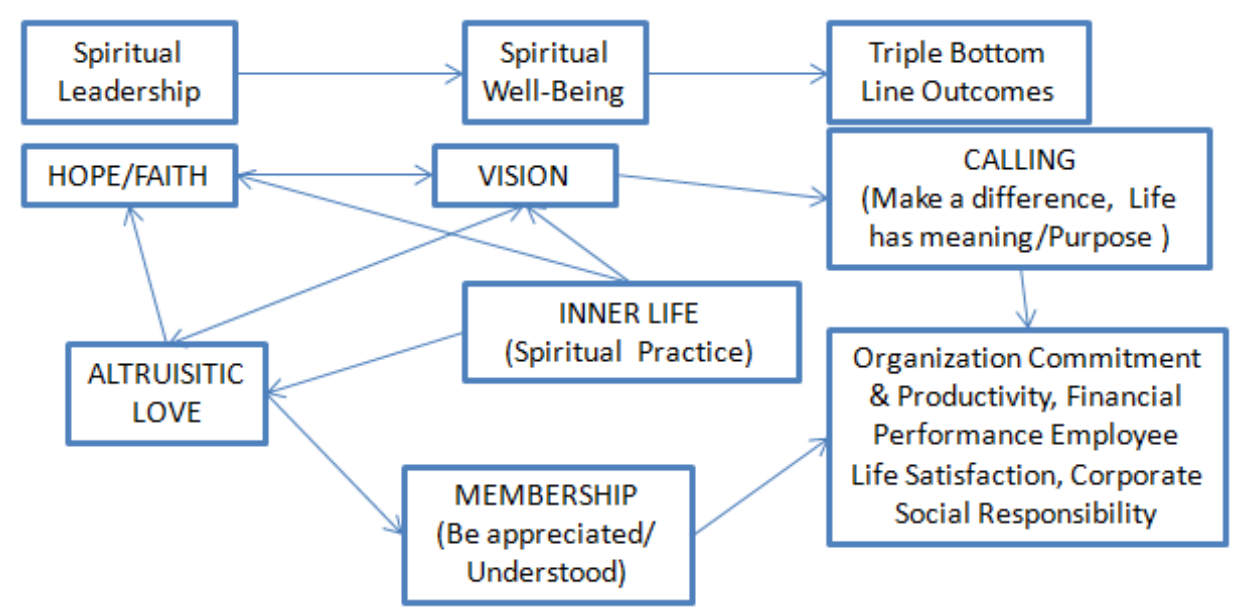

Figure 2: Model of Spiritual Leadership (Fry,2003)

3. Banerjee (1998) gave the Mother Leadership Model: the model encompasses all existing leadership styles, viz. visionary leader, servant leader, wisdom leader, missionary leader, intuitive leader, value-based ethical moral leader, proactive leader and authority-oriented leader. It is an integrative model of leadership based on the metaphor of mother.

\section{NEED FOR AN INTEGRATED PARADIGM: TOWARDS CONVERGENCE}

The way we think about leadership has parallels with our worldview and vice versa. Bennis (2007) suggested collaboration among social-neuro-cognitive scientists to move towards an integrative view on leadership. Emotional and spiritual intelligence capabilities are explored, as are concepts of leadership and "followership". Individual and collective mindsets/roles and their consequent behaviours, as experienced in the workplace, are identified and explored for their impact on organisational performance - again, from an integral perspective. Spirituality is the major constituent for most of the types of leadership. Without emphasising it, any leadership theory elaboration is not possible, because spirituality is the key driver in the primary leadership traits.

Physics has always influenced the worldview of management with its predictive, deterministic, scientific world view and a Darwinian world view. Now, modern physics is headed for a fresh start after being dominated by two camps in the twentieth century. The first upholds Einstein's relativistic model and the other supports the quantum model, maintaining that both the location and the energy of the particle cannot be known at the same time without an inherent degree of uncertainty. This whole pursuit is leading to the evolution of a unified theory of matter, field and energy. The theory holds promise for future discoveries of more dimensions of space and time.

Taking a clue from the physicists' endeavour towards understanding this complexity of matter in a unified way, we can examine leadership traits, which are being treated as fundamental particles or atoms of leadership, as nothing but projections of a single fundamental particle, i.e. spirituality in leadership. Leadership styles could be viewed as types of matter composed of traits the way elements are made of subatomic particles. This is a fresh start and indispensable to understanding complex observed phenomena in leadership, like non-linear inculcation of traits, will power, the leader's connectedness with people and environment, the nature of higher purpose or pursuits, and the source of intrinsic motivation. Similar directions have been seen in the development of activity theory that started from its constitution of subject, object and tools. Eventually, it incorporated environment and community. Let's examine the tracks of convergence of spirituality and leadership in the light of the need for an integrated paradigm.

Given the various tracks that researchers are pursuing, some of the apparent relationships are emerging, viz. leadership and spirituality, management practices and spirituality, organization performance and spirituality, etc. Fry (2003) observed that causal theories of spiritual leadership are developed with an intrinsic motivation model incorporating vision, hope, faith and altruism, workplace spirituality, spiritual survival and further religious, ethics and values-based approaches to leadership. The purpose of spiritual leadership is popularly 
believed to create vision/value synchronicity to promote higher levels of commitment and productivity. Management practitioners have started taking an integral approach towards leadership development. For instance, Hauen (2011) reported findings on an Inner leadership Program, a program that took an integral approach towards leadership and spirituality.

These are good steps, but there is also a probability that spirituality as a concept is not developed before it is put to superficial correlation-based application leading to its premature demise as a fad. Therefore it is imperative at this stage to develop the concept gradually with a healthy distance from existing ways of theorybuilding. This is done to ensure that this unique concept is not theorized in one or the other existing concept's image. Some of the questions which intuitively come to the authors:

- Can leaders with spiritual propensities be de-classified from any one or more of the types of leadership: charismatic, transformational, self, servant, etc?

- If leadership is beyond a leader as a person and about an aggregation of virtues, higher purpose and values, what is it that leaders follow?

- If there cannot be a complete spiritual person, can someone ever be called a spiritual leader or should it be said that he/she is on the path of spiritual leadership?

- Is spiritual leadership a journey or an end? If this phenomenon has infinite dimensions, how can this best be understood? How can this be inculcated? What is a higher purpose or ultimate purpose?

When a human understands even by way of inference the true nature of this creation, true relation existing between this creation and him, the bondages with the gross world disappear (H.H.S.Y. Giri, 1894), therefore in some scriptures this ultimate goal is termed as liberation also. Or in simpler words, it would be a pursuit for happiness, love or compassion and further emancipation. This remains as a fundamental approach for ages in finding answers to the questions above.

It is well understood that spiritual leadership is not confined to a particular culture. Intrinsic motivation towards knowledge and meaningful work has an influence on performance universally (Giacalone, 2003). Followers universally seek out a leader because of those positive attributes that are typically associated with spiritual behaviour rather than attributes related to social or cultural behaviour such as ambition, autonomy, directness, formality, cunning, etc (Sharma, 2010). Growing evidence in research shows consistency between spiritual values and effective leadership values and, is now forcing our attention to the confluence of spirituality and leadership. Table 5 is an attempt to draw them together.

Table 5: Comparison of Attributes of Leadership and Spirituality

\begin{tabular}{|l|l|l|}
\hline $\begin{array}{l}\text { Leadership Theory/ } \\
\text { Style/ Model }\end{array}$ & Characteristics & Associated Spirituality Concepts \\
\hline Spiritual Leadership & $\begin{array}{l}\text { Visioning process, work as calling, } \\
\text { concern for others, intrinsic motivation, } \\
\text { honest communication }\end{array}$ & $\begin{array}{l}\text { Trustworthiness, honest communication, } \\
\text { humility, trust in the leader, self-discipline, } \\
\text { community service, simplicity, individualized } \\
\text { consideration }\end{array}$ \\
\hline $\begin{array}{l}\text { Charismatic } \\
\text { Leadership }\end{array}$ & $\begin{array}{l}\text { Ignites followers' energy and } \\
\text { commitment }\end{array}$ & $\begin{array}{l}\text { Followers as immature and indecisive } \\
\text { individuals }\end{array}$ \\
\hline $\begin{array}{l}\text { Transformational } \\
\text { Charisma, inspirational motivation, } \\
\text { intellectual stimulation, individualized } \\
\text { consideration }\end{array}$ & $\begin{array}{l}\text { Instil optimism, confidence and faith for } \\
\text { achievement of goals }\end{array}$ \\
\hline $\begin{array}{l}\text { Emotional } \\
\text { Leadership }\end{array}$ & Re-experience shared emotions & $\begin{array}{l}\text { Empathy, ability to comprehend one's own } \\
\text { and other's feelings }\end{array}$ \\
\hline Servant Leadership & Delegators, teachers, facilitators & $\begin{array}{l}\text { Honest, trustworthy, service-oriented, } \\
\text { listening, healing, persuasive, good } \\
\text { communicators }\end{array}$ \\
\hline
\end{tabular}




\begin{tabular}{|c|c|c|}
\hline $\begin{array}{l}\text { Leadership Theory/ } \\
\text { Style/ Model }\end{array}$ & Characteristics & Associated Spirituality Concepts \\
\hline $\begin{array}{l}\text { Situational } \\
\text { Leadership }\end{array}$ & $\begin{array}{l}\text { Leadership style varies based on the } \\
\text { contingency of the situation }\end{array}$ & $\begin{array}{l}\text { Supportive, control-driven, persuasive, } \\
\text { participative decision-making }\end{array}$ \\
\hline Self Leadership & $\begin{array}{l}\text { Improvised action based on self-observed } \\
\text { feedback }\end{array}$ & Self-observation, self-management \\
\hline Great Man Theory & Leader as born and not made & Noble, wise, fit \\
\hline Ohio State Model & $\begin{array}{l}\text { Task-oriented leader and relationship- } \\
\text { oriented }\end{array}$ & $\begin{array}{l}\text { Encouraging, control-driven, motivating, task } \\
\text { quality-oriented }\end{array}$ \\
\hline Contingency Model & $\begin{array}{l}\text { Leader-member relations, task structure, } \\
\text { leader's position power }\end{array}$ & Confidence building, optimism \\
\hline Traits Theory & Leadership traits can be acquired & $\begin{array}{l}\text { Excellence orientation, win/win problem- } \\
\text { solving }\end{array}$ \\
\hline Process Theory & Leader as facilitator & $\begin{array}{l}\text { Trust, intimacy, subtlety, reduced control, } \\
\text { humility }\end{array}$ \\
\hline Behavioural Theory & Leader behaviour and follower willingness & $\begin{array}{l}\text { Ability to motivate followers, willingness and } \\
\text { ability of the follower }\end{array}$ \\
\hline $\begin{array}{l}\text { Leader Member } \\
\text { Exchange Theory }\end{array}$ & Individualized & High relationship orientation \\
\hline Path Goal Theory & $\begin{array}{l}\text { Situational context moderators found in } \\
\text { leaders }\end{array}$ & Interpersonal relations \\
\hline $\begin{array}{l}\text { Additional Effective } \\
\text { Leadership Traits }\end{array}$ & $\begin{array}{l}\text { Optimism, trustworthiness, justice, win- } \\
\text { win problem-solving, encouraging, } \\
\text { motivating, communicativeness, } \\
\text { excellence orientation, confidence } \\
\text { building, honesty, dynamism, team- } \\
\text { building, dependability }\end{array}$ & $\begin{array}{l}\text { Trust, integrity, honesty, humility, openness, } \\
\text { compassion, caring, listening responsively, } \\
\text { reflective, appreciating contribution (Reave, } \\
\text { 2005); } \\
\text { Ruthless, asocial, irritable, loner, egocentric, } \\
\text { non-cooperative, dictatorial (Hartog et al., } \\
2003 \text { ) }\end{array}$ \\
\hline
\end{tabular}

Interestingly, most of the Eastern models traditionally have spirituality already infused. This is evident in Table 6 below. 
Table 6: Comparison of Attributes of Eastern Models of Leadership with Spirituality Attributes

\begin{tabular}{|c|c|c|}
\hline Theory & Common Characteristics & $\begin{array}{l}\text { Associated Spirituality Concepts and } \\
\text { Remarks }\end{array}$ \\
\hline Vijigshu Model & Sam, Dam, Dand, Bhed, Loksangraha & Ability to articulate vision ${ }^{1}$ \\
\hline Nurturant-Task Leadership & Considerate and affectionate & Participative decision making $^{1}$ \\
\hline Karta Model & Protector and guardian & Foresight $^{1}$ \\
\hline $\begin{array}{l}\text { Four Steps Enlightened } \\
\text { Leadership }\end{array}$ & $\begin{array}{l}\text { Vision, enlightenment, devotion and } \\
\text { action, higher purpose }\end{array}$ & $\begin{array}{l}\text { Degree of intensity of characteristics } \\
\text { vary as per Samkalp Shakti }{ }^{1}\end{array}$ \\
\hline Yin-Trinity Model & $\begin{array}{l}\text { Righteous use of wealth, knowledge } \\
\text { and power }\end{array}$ & $\begin{array}{l}\text { Shishya lakshan - form the bedrock for } \\
\text { these characteristics }\end{array}$ \\
\hline Workship Model & $\begin{array}{l}\text { Discipline, righteousness, sacrifice, and } \\
\text { transcendence }\end{array}$ & Disciplined spiritual practice ${ }^{2}$ \\
\hline Rishi as Re-see Model & Self-responsible & Self-management ${ }^{1}$ \\
\hline Kautilya model & $\begin{array}{l}\text { Sharp mind, energetic, resoluteness of } \\
\text { purpose, learnability, skill }\end{array}$ & $\begin{array}{l}\text { Self-management }{ }^{1} \text {, meaningfulness in } \\
\text { work }^{3}\end{array}$ \\
\hline Panchsheela Model & $\begin{array}{l}\text { Satya, Ahimsa, Asteya, Aparigraha and } \\
\text { Brahmacharaya }\end{array}$ & Honest communication $^{1}$ \\
\hline
\end{tabular}

1 Shown as outcome, in the form of leaves/branches in Figure 3.

2 Shown in the form of trunk in Figure 3.

3 Shown in the form of branches that form the roots in Figure 3.

The above tables do not cover all theories and styles. The table is intended to demonstrate that spirituality spans across major leadership theories and styles. Most of them appear incomplete without incorporating spiritual features. Further, there is a need to establish spirituality as leadership's bedrock with certain identical features mentioned in the table given below.

Table 7: Snapshot of Keywords Associated with Spirituality and Leadership

\begin{tabular}{|c|c|}
\hline Spirituality & Leadership \\
\hline $\begin{array}{l}\text { Individual, collective, values, attitudes, behaviours, } \\
\text { intrinsic, calling, membership, ultimate or higher } \\
\text { purpose, imagination, joy, spontaneity, creativity, } \\
\text { discernment, ignorance, wonder, subconscious, } \\
\text { unconscious, super conscious, non-linear } \\
\text { manifestation, faith, connectedness, serving, inner } \\
\text { transformation, impacts organisation performance, } \\
\text { sthithpragyata: ability to witness one's thoughts, self- } \\
\text { driven, nishkam karm, sadachaar, altruistic love, } \\
\text { intrinsic motivation, character and integrity, honest } \\
\text { communication, conscience and values, hope/faith, } \\
\text { concern for others }\end{array}$ & $\begin{array}{l}\text { Interpersonal, psychological, contextual, satisfaction, } \\
\text { motivation, trust, intimacy, subtlety, reduced control, } \\
\text { humility, facilitator, shared, collective, loksangraha, } \\
\text { vision, enlightenment, devotion, action, higher } \\
\text { purpose, righteous use of wealth, knowledge and } \\
\text { power, discipline, righteousness, sacrifice, } \\
\text { transcendence, self-responsible, resoluteness of } \\
\text { purpose, Satya, Ahimsa, Asteya, Brahamcharya, } \\
\text { Aparigrah, willingness to make radical changes, } \\
\text { empathy, shared emotional experiences, global, self- } \\
\text { observation, self-management, listening, empathy, } \\
\text { healing, awareness, persuasion, conceptualization, } \\
\text { foresight, stewardship, commitment, building } \\
\text { community, supportive, participative decision-making }\end{array}$ \\
\hline
\end{tabular}


The metaphoric representation in the form of a tree (Figure 3) depicts the relationship of spirituality and leadership, wherein the roots are spiritual prerequisites or shishya lakshan, the trunk maintains the strength of shishya lakshan through disciplined spiritual practice, the branches are leadership traits - self-management, creating shared emotional experiences (Lord De Vader \& Alliger, 1986), foresight (Russell \& Stone, 2002), participative decision-making (Vroom \& Yetton, 1973), ability to articulate vision (Bass, 1997), honest communication (Fry, 2003) and branches extending to form roots - positive work relationship, meaningfulness in work, ethical conduct, social responsibility (results that the leader creates for the organization which becomes the further basis for operational purposes)

Shaante, shudhe, sadachaare, gurubhaktayekmanase, dridchitta, kritagya che deya chaiva swarayodayam

(Shiv Swarodya, verse 13)

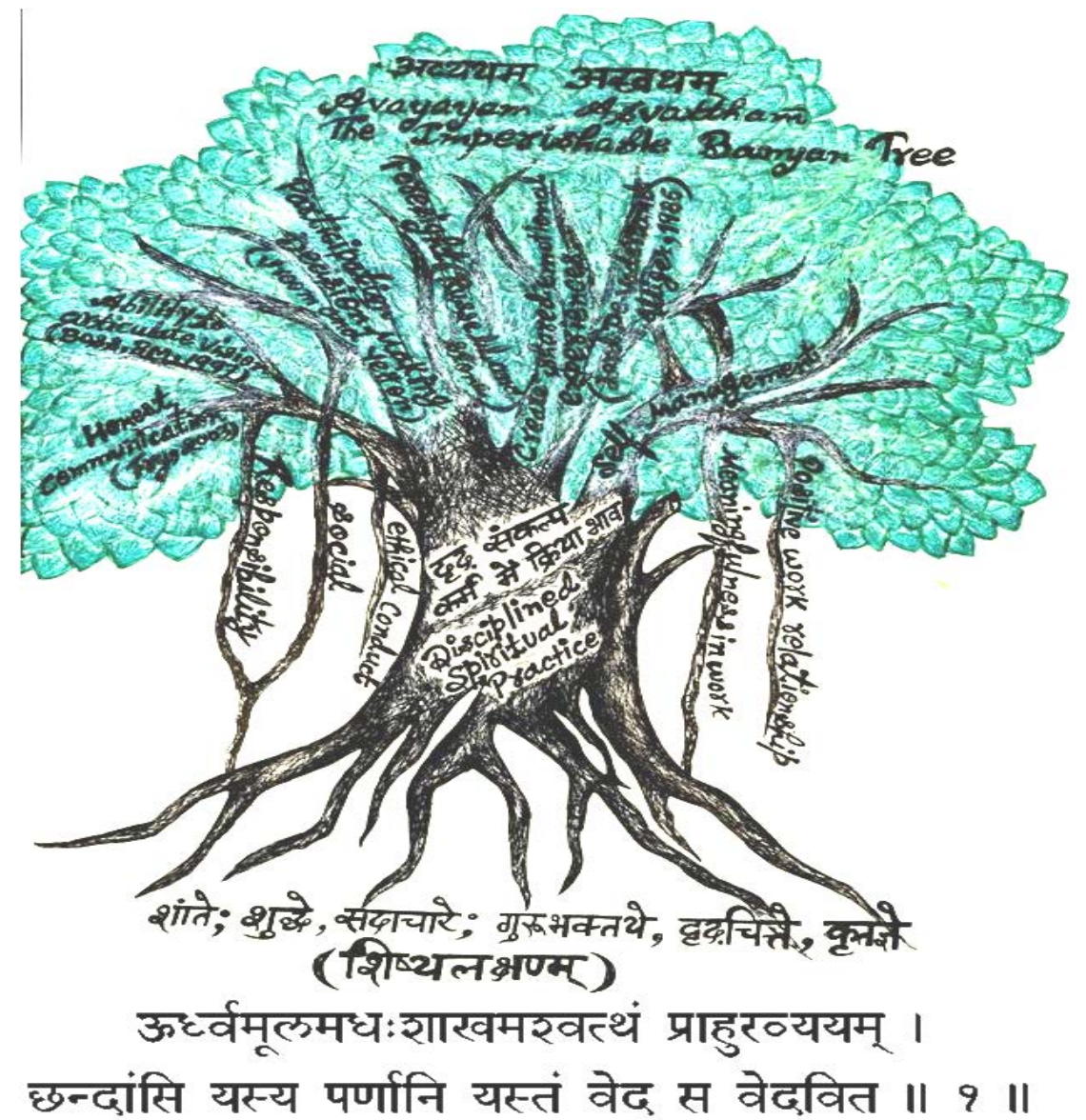

Figure 3: Metaphorical Representation of Spirituality and Leadership Features

Shishya lakshan shown in the figure (Figure 3) form the platform for unheralded growth in this lifetime. Selfmanagement, participative decision-making, foresight, ability to articulate vision, and honest communication are the leadership traits that are spiritual in their very nature. The branches that form the roots are the apparent behavioural practices that form the platform (or further bedrock) for organizational effectiveness. The innate self has a trunk made of disciplined spiritual practice and the leadership traits are only a sample indication of the unheralded growth. The indicative bedrock consists of organizational values such as ethical conduct, positive work relationship, meaningfulness in work and social responsibility. These values emanate from the individual value system contributed by the person actively following the above tree, which will eventually lead a person to a position of leadership irrespective of the current state. However, the time in which the leadership position is achieved may vary based on the intensity of practice of the above by an individual. 


\title{
मृदु मध्याधिमात्रत्वतत्तोअपि विशेष:
}

\author{
mridumadhyadhimaatrtvattoapi vishesh
}

For those who practice intensely, it would be achieved very soon. Then there are even more ratings, according to intense, mediocre or slight practice. (Patanjali Yogsutra, verse 22)

\section{CONCLUSION}

These two pervasive constructs, leadership and spirituality, have the potential to improve the workplace, humanity, and the environment, only if they are defined and practiced in an integrated way by people. There is also a need to develop spiritual leadership theory encompassing all the world views, including the ones which are not dominant in organizations. The imperative at this stage is to develop the concept gradually with a healthy distance from existing ways of theory-building, to make sure that this unique concept is not theorized in one or the other existing concept's image. The field of study would be highly enriched if it can obtain the inputs of scholars well-versed with ancient literature, especially from the times when there were fewer religions or belief systems. This can help us decipher commonalities at a human level with regards to spirituality and its epiphanies. As evident from the ancient and contemporary literature, spirituality has to be an intrinsic aspect of leadership regardless of its ways of practice.

Authors would like to conclude by stating that spirituality and leadership cease to exist separately after a certain hypothetical point in the journey of leadership development. Therefore, it would not be wrong to mention that spiritual leadership is always a path and not a destination/end for a person. There can be various ways to reach the zenith of spirituality and leadership. There are many approaches which various scriptures in every part of the world have suggested. Some of the indicative features in the Eastern approach consist of:

- Encountering, exploring, training and eventually transcending mind

- Being able to understand thought's nature as Klishta* or aklishta* brings freedom of choice to act or not act

- Cultivating a Sattvic or illumined mind while allowing Tamas to bring stability and Rajas to bring positive action.

- Restraint or Samyama* while treading towards the ultimate objective, Sankalpa*.

Spiritual practitioners across the world have realized these features in their own ways of practice. The researchers' arrival would take a while, but fortunately the researcher community appears to be on course. In coming years, we will surely get to see the evolution of leadership as something that emanates from the bedrock of spirituality and is intrinsically driven.

\section{FUTURE RESEARCH AVENUES}

Some interesting observations came up during this work with regards to the profile of researchers and the nature of the material to which they refer. Incidentally, the majority of the researchers in this field hail from a geographical subset, namely, US, UK, Australia and The Netherlands. Plenty of literature which was not adequately studied or quoted falls in the non-academic realm and is available as ancient scriptures, discourses and spiritual lectures. Since this study is fundamental in nature, the degree of diversity of worldviews of the researchers with respect to religion, ethnicity, culture and belief systems would play an important role here. Therefore, collaborative research, ensuring diversity of participants, would help to come up with holistic paradigms, if this concept is believed to be of interest at the human development level.

A word of caution worth mentioning here is that literature searches in the mainstream body of knowledge may be biased or skewed towards one or few directions or research approaches, thereby limiting discoveries. Epistemology and ontology are still in the process of being established for concepts like spirituality. Even the authors have disagreements with the literature; we tacitly or unknowingly tend to agree with the concept being given a certain field of study categorization. For instance, the researchers' discipline or Shishya lakshan towards the source of knowledge, including scriptures, plays an important role in the study of spirituality and inner leadership through spirituality. The research on establishing the convergence of spirituality and leadership should be continued, incorporating various worldviews and related concerns mentioned above. 
Puneet Bindlish is a research scholar at the Management Development Institute (MDI), Gurgaon, India. He has corporate work experience of about a decade with organizations like Wipro, Oracle, Infosys and two successful entrepreneurial stints. He holds a Bachelor degree in Mining Engineering from the Indian Institute of Technology, BHU, Varanasi. His research interests include Entrepreneurship, Technology and Spirituality in Management.

Priyanka Dutt is an Assistant Professor in the Department of Management Studies at IIS University, Jaipur. She has corporate experience and has worked as Manager HR with organizations like Vodafone, Unitech Ltd and Marico Ltd. Her last experience was with Vodafone Essar Digilink Pvt Ltd as the Learning and Development Lead for Rajasthan circle. She holds a Masters degree in Personnel Management and Industrial Relations from Tata Institute of Social Sciences, Mumbai. Her research interests include leadership, spirituality and exploration of the Indian culture through requisite travel.

Rupali Pardasani is a research scholar at Management Development Institute (MDI), Gurgaon, India. She is pursuing the Fellow Programme in Management in the area of organizational behaviour at MDI. Prior to this she worked as Assistant Professor of $\mathrm{HR} / \mathrm{OB}$ at an affiliate institute of Guru Gobind Singh Indraprastha University, Delhi. She holds a Masters and a Bachelors degree in Business Administration from Guru Gobind Singh Indraprastha University, Delhi. Her research interests include leadership, spirituality at the workplace, cross-cultural studies and intra-psychic processes in individuals.

\section{Acknowledgments}

The authors would like to express their gratitude to Prof. Sharda Nandram (Associate Professor at Nyenrode Business University, Professor HAN University of Applied Sciences, The Netherlands) for her continued guidance. Also we are grateful to Prof. Radha R. Sharma (MDI, Gurgaon), Prof. Rajen Gupta (MDI, Gurgaon), Shaveta Bindlish and Somesh Dutt for their able guidance and support in various capacities.

\section{GLOSSARY}

\begin{tabular}{|c|c|c|c|}
\hline Agama/Shruti: & Verbal, apourusheya & Klishta : & Troublesome, difficult, tough, \\
\hline Ahimsa: & Non-Violence & Loksangraha: & People welfare \\
\hline \multirow[t]{3}{*}{ Aklishta: } & Non-troublesome, which is not & Moksha: & Transcendence \\
\hline & difficult and easy to do or & Panchmah: & Five \\
\hline & understand & Panchsheela: & Five principles \\
\hline Anumana: & Inference & Pratyaksha: & Perception \\
\hline Anupalapdhi: & Non-apprehension & Rajas: & Activity or drive, passion \\
\hline Aparigraha: & $\begin{array}{l}\text { Non-attachment/Non- } \\
\text { possession }\end{array}$ & Rajrishi: & $\begin{array}{l}\text { A king who has left the kingdom } \\
\text { and became saint and }\end{array}$ \\
\hline Apourusheya: & Not a human creation & & renunciant \\
\hline Arthapatti : & Presumption & Rishi: & Sage, Saint \\
\hline Asteya : & Non-Stealing & Sam: & Persuasion \\
\hline Bhakti/Upasana: & Devotion & Samadhi: & Super-consciousness \\
\hline Bhed: & Power division & Samkalp Shakti: & Power to stay resolute on the \\
\hline Brahmacharya: & Celibacy/Chastity & & path \\
\hline Brahman: & Creation, Universe & Samyama: & Restraint \\
\hline $\begin{array}{l}\text { Chitta Shudhi: } \\
\text { Dam: }\end{array}$ & $\begin{array}{l}\text { Purification of body and mind. } \\
\text { Economic incentives }\end{array}$ & Sankalpa: & $\begin{array}{l}\text { Strong determination to do } \\
\text { something }\end{array}$ \\
\hline $\begin{array}{l}\text { Dand: } \\
\text { Dharma: }\end{array}$ & $\begin{array}{l}\text { Punishment } \\
\text { Religion }\end{array}$ & Sattva: & $\begin{array}{l}\text { Purity and illumination, } \\
\text { goodness }\end{array}$ \\
\hline Ekagra chitta: & $\begin{array}{l}\text { One-pointedness of body and } \\
\text { mind }\end{array}$ & $\begin{array}{l}\text { Satya: } \\
\text { Shishya lakshan: }\end{array}$ & $\begin{array}{l}\text { Truth } \\
\text { Characters of disciple }\end{array}$ \\
\hline Gyan: & Revelation, knowledge & Shlokas: & Verses \\
\hline Jiva: & Living Being & Shradha: & Reverence \\
\hline Karma: & $\begin{array}{l}\text { Past and present actions } \\
\text { capable of creating good/bad } \\
\text { results. }\end{array}$ & $\begin{array}{l}\text { Sneh: } \\
\text { Tamas: } \\
\text { Upamana: }\end{array}$ & $\begin{array}{l}\text { Affection } \\
\text { Darkness, ignorance } \\
\text { Comparison }\end{array}$ \\
\hline Karta: & $\begin{array}{l}\text { Doer, or the head of a joint/ } \\
\text { extended family }\end{array}$ & Vijighsu: & $\begin{array}{l}\text { Vijaya (victory) Ikshuk } \\
\text { (desirous), desirous of victory }\end{array}$ \\
\hline
\end{tabular}




\section{REFERENCES}

Amabile, T. M., Schatzel, E. A., Moneta, G. B. \& Kramer, S. J. (2004). Leader behaviours and the work environment for creativity: Perceived leader Support, The Leadership Quarterly. 15(1), February, 5-32.

Ashmos, D. and Duchon, D. (2000). Spirituality at work: A conceptualization and measure, Journal of Management Inquiry. 9(2), 134-145.

Avolio, B. J., Gardner, W. L., Walumbwa, F.O., Luthans, F. \& Douglas R. M. (2004). Unlocking the Mask: A look at the process by which authentic Leaders impact follower attitudes and behaviours, The Leadership Quarterly (15)6, 801-823.

Avolio, B. J., Kahai, S. \& Dodge, G. E. (2001). E-leadership: Implications for theory, research, and practice. The Leadership Quarterly, 11(4), 615-668.

Avolio, B.J. \& Luthans, F. (2006). The high impact leader: Moments matter for accelerating authentic leadership development. New York: McGraw-Hill.

Avolio, B.J. (2007). Promoting more integrative strategies for leadership theory building. American Psychologist, 62, 25-33.

Banerjee, R.P. (1998). Mother leadership. Allahabad: Wheeler Publishing.

Barker, R. (2002). On the nature of leadership. New York: University Press of America.

Bass, B. M. (1997). Does the transactional-transformational leadership paradigm transcend organizational and national boundaries? American Psychologist, 52(2), 130.

Bass, B. M. (1998). Transformational leadership: Industry, military, and educational impact. Mahwah, NJ: Erlbaum.

Bass, B. M. (2000). The future of leadership in learning organizations. Journal of Leadership \& Organizational Studies, 7(3), 18-40.

Bell, E. \& Taylor, S. (2001). A rumor of angels: Researching Spirituality and work organizations, Proceedings of the Academy of Management. MSR: A1.

Benefiel, M. (2005). The Second half of the Journey: Spiritual leadership for Organizational Transformation, The Leadership Quarterly, 16(5), 723-747.

Bennis, W. G. \& Nanus, B. (2007). Leaders: The strategies for taking charge. New York, NY: HarperCollins.

Bhatt, Govardhan P. (1989). The Basic Ways of Knowing: An In-depth Study of Kumārila's Contribution to Indian Epistemology. Delhi: Motilal Banarasidass.

Bhatt, Panduranga, C. (2000). Leadership values: Insights from Ashoka's inscriptions. Journal of Human Values, July-December, 6(2), 103-113.

Bhatta, Panduranga, C. (2000). Leadership values: Insights from Ashoka's inscriptions. Journal of Human Values, July-December, 6(2), 103-113.

Biberman, J. \& Altman, Y. (2004). Welcome to the New Journal of Management, Spirituality and Religion, Journal of Management, Spirituality and Religion.

Bierly, P. III, Kessler, E. \& Christensen, E. (2000). Organizational learning, knowledge and wisdom, Journal of Organizational Change Management, 13(6), 595-618.

Braud W. \& Anderson R. (1998), Transpersonal Research Methods for the Social Sciences. California: Sage Publications.

Burns, J. M. (1978). Leadership. New York: Harper \& Row.

Cacioppe, R . (2000). Creating spirit at work: Re-visioning organization development and leadership-Part II. Leadership \& Organization development Journal, 21(2), 110-119.

Cavanaugh, G., Hanson, B., Hanson, K., and Hinojoso, J.: 2001, Toward a Spirituality for the Contemporary Organization: Implications for Work, Family and Society. In Champoux, J.E. (Ed.) (2000). Organizational Behavior: Essential tenets for a new millennium. Cincinatti, $\mathrm{OH}$ : South-Western College Publishing. 
Chakraborty, S. K. (1990), Human response development: Exploring transformational values. New Delhi: Wiley Eastern Ltd, 110-118.

Chakraborty, S.K. (1999). Wisdom leadership: Dialogues \& reflections. New Delhi: Wheeler Publishing.

Chatterjee, Debasis (1998), Leading By Consciousness: A Pilgrimage Towards Self Mastery, New Delhi: Viva Books, 64.

Chernow, R. (2004) Alexander Hamilton's last stand. The New York Times (2004, July 11), p. 13 (Section 4).

Clements, C. and Washbush, J. B. (1999). The Two faces of leadership: Considering the dark side of leaderfollower dynamics, Journal of Workplace Learning, 11(5), 170-175.

Cook-Greuter, Susanne (2002). A detailed description of the development of nine action logics in the leadership development framework: Adapted from ego development theory. Available http://www.cookgreuter.com/

Dansereau, F. (1996). A dyadic approach to leadership: Creating and nurturing this approach under fire. The Leadership Quarterly, 6(4), 479-490.

Dansereau, F. E. \& Yammarino, F. J. (1998). Leadership: The multiple-level approaches: Contemporary and alternative. Elsevier Science/JAI Press.

Dansereau, F., Graen, G. \& Haga, W. J. (1975). A vertical dyad linkage approach to leadership within formal organizations: A longitudinal investigation of the role making process. Organizational Behavior and Human Performance, 13(1), 46-78.

Delbecq. A. (1999). Christian Spirituality and contemporary business leadership, Journal of Organizational Change Management, 12(4), 345-349.

Dent, E. B., Higgins, E. M. \& Wharff, D. M. (2005). Spirituality and leadership: An Empirical Review of Definitions, Distinctions, and Embedded assumptions, The Leadership Quarterly, 16(5), 625-653.

Dickson, M. W., Hartog, D. N. D. \& Mitchelson, J. K. (2003). Research on leadership in a cross-cultural context: Making progress, and raising new questions. The Leadership Quarterly, 14, 729-768.

Drath, W. H., \& Palus, C. J. (1994). Making common sense: Leadership as meaning-making in a community of practice. Greensboro, NC: Center for Creative Leadership.

Eggert, N. (1998). Contemplative leadership for entrepreneurial organizations: Paradigms, metaphors, and wicked problems. Quorum Books.

Elm, D.R. (2003). Honest, spirituality and performance at work. In R.A. Giacolone and C.L. Jurkiewicz (Eds.), Handbook of workplace spirituality and organizational performance, 277-288. NewYork: M.E. Sharpe.

Fairholm, G. W. (1998). Perspectives on leadership: From the science of management to its spiritual heart. Westport, CT: Praeger.

Fry, L. W. (2003). Toward a theory of Spiritual leadership, The Leadership Quarterly, 14(6), 693-727.

Giacalone, R. A. \& Jurkiewicz, C.L. (2003). Handbook of Workplace Spirituality and Organizational Performance, Journal of Business Ethics, 16(5), 655-687.

Gibbons, P. (2011). Spirituality at Work: Definitions, measures, assumptions, and validity claim. Birkbeck College, University of London. Submitted Thesis on 12th April.

Giri, S. Y. (1894). The Holy Science, Ananda Sangha Publication. ISBN: 81-89535-19-6, YSS.

Glad, B. (2002). Why tyrants go too far: Malignant narcissism and absolute power. Political Psychology, 23(1), 1-2.

Goldsmith, M. (2003). Global leadership: The next generation. Ft Press.

Goparaj, H. \& Sharma, R. (2009). Emotional Intelligence, Vedic and Modern Perspectives Paper presented at Inaugural Indian Academy of Management Conference at XLRI, Jamshedpur, India: 28-30 December.

Green, M. T., Duncan, P. \& Kodatt, S. A. (2011). The relationship between follower ratings of leadership and the leaders' spirituality, Journal of Spirituality, Leadership and Management, 5(1), 46-57. 
Greenleaf, R. K. (1970). The leader as servant. New York: Paulist Press.

Greenleaf, R. K. (1998). The Power of Servant Leadership. San Francisco.

Hauen, P. V. (2011). Applying an integral approach to leadership development for an Australian public health service, Journal of Spirituality, Leadership and Management, 5(1), 25-36.

Hazy, T. E., Frank, M. J. \& O'Reilly, R. C. (2007). Towards an executive without a homunculus: computational models of the prefrontal cortex/basal ganglia system. Philosophical Transactions of the Royal Society B: Biological Sciences, 362(1485), 1601-1613.

Howard, S. (2002). A Spiritual Perspective on learning in the workplace, Journal of Managerial Psychology, 17(3), 230-242.

Jain, N. \& Mukherji, S. (2009). Communicating a holistic perspective to the world: Kautilya on Leadership, Leadership \& Organization Development Journal, 30(5), 435-454.

Jain, N. (2011). Panchsheela Model of Leadership: A Model for Organizational Survival and Growth Journal of Human Values. April, 17, 43-61.

Jong, J. P. J. \& Hartog, D. N. D. (2007). How leaders influence employees' innovative behaviour, European Journal of Innovation Management, 10, 41-64.

Khanna, H. \& Srinivas, E. (2000), Spirituality and leadership development. Presented to the roundtable conference on developing leaders, teams, and organizations: Meeting the challenges of global markets and technology. Management Development Institute, Guragon.

Kimhi, S. (2001). Benjamin Netanyahu: A psychological profile using behavior analysis. Profiling Political Leaders: Cross-Cultural Studies of Personality and Behavior, 149.

Kramer, R.M. (2003).The imperatives of identity: The role of identity in leader judgment and decision making. In D. van Knippenberg \& M. Hogg (Eds.), Leadership and power: Identity processes in groups and organizations, London: Sage, 184-196.

Krishnan, V.R. (2001). Can the Indian Worldview Facilitate the Emergence of Transformational Leaders? Management and Labour Studies. 26 (4), 237-244.

Krugman, P. (2005). Questions of Character. New York Times, October 14.

Lane, H. W., Maznevski, M. L., McNett, J. \& Mendenhall, M. E. (2004). The Blackwell handbook of global management: A guide to managing complexity. London: Blackwell.

Lord, R. G., De Vader, C. L., \& Alliger, G. M. (1986). A meta-analysis of the relation between personality traits and leadership perceptions: An application of validity generalization procedures. Journal of Applied Psychology, 71(3), 402.

MacDonald, D.A., Kuentzel, J.G. \& Friedman, H.L. (1999). A Survey of measures of spiritual and transpersonal constructs: Part Two - Additional instruments, Journal of Transpersonal Psychology, 31(2), 155-177.

Manz, C. C., \& Sims, H. P. (1980). Self-Management as a Substitute for Leadership: A Social Learning Theory Perspective. Academy of Management Review, 5(3), 361-368.

Mason, E. \& Welsh, A. (1994). Symbolism in managerial decision making, Journal of Managerial Psychology, 9(6), 27-35.

Miliora, M. T. (2006). The psychology and ideology of an Islamic terrorist leader: Usama bin Laden. International Journal of Applied Psychoanalytic Studies, 1(2), 121-139.

Mobley, W. (1999). Advances in Global Leadership, volume 1.

Pandey, S. K. \& Walli, O.P (2010). Management Lessons from Indian Epics in Context to Theory Z, Journal of Human Values, 16, 57.

Patterson, K. A. (2003). Servant leadership: A theoretical model. Doctoral dissertation, Regent University (UMI No. 3082719).

Pfeffer, J. \& Salancik, G. (2003). The external control of organizations: A resource dependence perspective. Stanford Business Books. 
Rao, G.P. (1990). Work ethics and Indian psycho-philosophy: Some ideas on a maternalistic model. Sage Publications, India.

Reave, L. (2005). Spiritual values and practices related to leadership effectiveness, The Leadership Quarterly, $16(5), 655-687$.

Reichers, A. E. \& Schneider, B. (1990). Climate and culture: An evolution of constructs. In B. Schneider (Ed.), Organizational climate and culture. San Francisco: Jossey-Bass Publishers, 5-40.

Renshon, S. A. (2001). Dual citizenship and American national identity. Washington^ eDC DC: Center for Immigration Studies.

Robbins, S. P. (2003.) Organizational Behaviour (10th Edition), Englewood Cliffs, NJ: Pearson Education.

Rost, J.C. (1993). Leadership development in the new millennium. The Journal of Leadership Studies, November, 91-110.

Russell, R.F. \& Stone, A.G. (2002). A review of servant leadership attributes: developing a practical model. Leadership \& Organization Development Journal, 23(3), 145-157.

Sanders, J. E., Hopkins, W. E. \& Geroy, G. D. (2003). From transactional to transcendental: Toward an integrated theory of leadership. Journal of Leadership and Organizational Studies, 9(4), 21-31.

Seibert, S. E., Sparrowe, R. T. \& Liden, R. C. (2003). A group exchange structure approach to leadership in groups. In Pearce, C. L. \& Conger, J. A. Shared leadership: Reframing the hows and whys of leadership. Thousand Oaks, CA: Sage Publications.

Seibert, S. E., Sparrowe, R. T. \& Liden, R. C. (2003). A group exchange structure approach to leadership in groups. In Pearce, C. L. \& Conger, J. A., Shared leadership: Reframing the hows and whys of leadership. Thousand Oaks, CA: Sage Publications.

Sharma, R. R. (2010). Preventing Corruption through Spiritual Leadership in Organisations, Organization and Management, 14, 729-768.

Sharma, S. (1995). Towards enlightened leadership: A framework of leadership and management. Corporate Rishi-Leadership Model.

Sharma, S. (1996). Management in New Age: Western Windows, Eastern Doors, New Age International Publishers, New Delhi.

Sharma, S. (1998). Enlightened Leadership in Indian Ethos: The Way of theory K, Management \& Change, JanJune, 2(1), 93-104.

Sharma, S. (2001). Routes to Reality: Scientific and Rishi Approaches, Journal of Human Values, Jan-June, 7(1), 75-83.

Sharma, S. (2002). Corporate Rishi Leadership Model: An Indian model for corporate development \& ethical leadership, Human Resource Development in Asia: Trends \& Challenges, Oxford \& IBH, New Delhi, 219-296.

Sharma, S. (2011). Emergence of Indian Management: Towards New Mantras in Corporate Corridors, Conference Chair, Global Impact of Indian Management, organized by Department of Business Administration, The Oxford College of Engineering, Bangalore, on April 27-28, 2011, Director, Indus Business Academy (IBA), Bangalore.

Singh, P. \& Bhandarkar, A. (1990). Corporate Success and Transformational Leadership. New Delhi: Wiley Eastern Ltd.

Singh, P. \& Bhandarkar, A. (2011). In Search of Change Maestros, SAGE Publication.

Sinha, J.B.P. (1980). Nurturant Task Leadership. New Delhi : Concept.

Stogdill , R. M. (1948). Personal factors associated with leadership: A survey of the literature. Journal of Psychology, 25, 35-71.

Strack, G., Fottler, M., Wheatley, M. \& Sodomka, P. (2002). Spirituality and effective leadership in healthcare: Is there a connection? Frontiers of Health Services Management, 18(4), 3-45.

Suskind, R. (2004). Without a doubt. New York Times Magazine. October 17: 44. 
Thompson, C. M. (2000). The congruent life: Following the inward path to fulfilling work and inspired leadership. San Francisco: Jossey-Bass.

Wilber, K. (2000a). Integral Psychology: Consciousness, Spirit, Psychology, Therapy. Boston: Shambhala.

Wilber, K. (2000b), A Theory of Everything: An Integral Vision for Business, Politics, Science and Spirituality. Boston: Shambhala.

Wolman, R. (2001). Thinking with your soul. Harmony Books.

Yammarino, F. J., Dionnea, S. D., Chun, J. U. \& Dansereau, F. (2005). Leadership and levels of analysis: A stateof-the-science review, The Leadership Quarterly Yearly Review of Leadership, 16(6), 879-919.

Yukl, G. (2006). Leadership in organizations (6th ed.). Upper Saddle River, NJ: Prentice Hall.

Zee, H.J. (1980). The Guyana incident: Some psychoanalytic considerations. Bulletin of the Menninger Clinic, 44: 345-363.

Zigurs, I. (Ed.) (2003) e-Service Journal. 